\title{
AN IN-HOUSE MULTIPLEX PCR METHOD TO DETECT OF PUTATIVE VIRULENCE FACTORS IN Aeromonas SPECIES
}

\author{
Ma. Guadalupe Aguilera-Arreola, Alma Aidee Carmona Martínez, Graciela Castro-Escarpulli* \\ Escuela Nacional de Ciencias Biológicas, Instituto Politécnico Nacional, Mexico, D.F.
}

Submitted: November 03, 2010; Returned to authors for corrections: March 04, 2011; Approved: May 30, 2011.

\begin{abstract}
A pentaplex PCR was developed and optimised to detect the genes that encode the five most important putative virulence factors in Aeromonas isolates. It seems to be more efficient than previously reported techniques and promises to be a powerful tool for more accurate risk assessments and for monitoring pathogenic strains.
\end{abstract}

Key words: pentaplex-PCR, virulence potential, pathogenesis, Aeromonas.

Aeromonas spp. have been considered autochthonous inhabitants of aquatic environments. However, some species have a broad host spectrum, causing intestinal and extraintestinal infections in humans, as well as furuncles, hemorrhagic septicaemia, and soft tissue infections in fish. In spite of the taxonomic expansion of the genus, which currently includes 25 species, only 3 species are of clinical importance in humans $(3,4,5,17,20,23,25)$. Interest in the pathogenicity of these microorganisms has become relevant due to their increasing implications in human diseases. The pathogenic mechanism of Aeromonas spp. has not yet been elucidated. Some studies have indicated that their pathogenicity could entail a complex mechanism involving multiple virulence factors, in which these bacteria attach to and colonise the lumen of the intestine and give rise to several enterotoxins (15, 20, 23, 30). Moreover, no single virulence factor or combination of factors has been unequivocally correlated with virulence in the different species. Therefore, the continuous monitoring of several virulence factors in clinical, food, and environmental Aeromonas isolates remains an important tool in the understanding of both pathogenesis and epidemiology of Aeromonas infections. The detection of genes coding for bacterial adhesins, biofilm formation, and secreted enzymes, such as lipases, haemolytic enterotoxins, proteases, and nucleases has been considered a crucial step to ascertain the virulence potential of isolates $(2,7,10,19,26,27,28,29)$.

In the last years, at least five different types of m-PCR have been described in the literature $(11,12,22,26,28)$. Some authors have described their own approach to detect simultaneously two or more virulence genes in Aeromonas and have employed it in drinking water isolates (12), several kinds of food $(11,21,22)$, and fish (26). In all of these publications, the isolates possessed a wide variety of virulence-related genes, suggesting the importance of examining as many isolates as possible to understand better the health risks posed by these bacteria (28). These studies described results reviewed the array of virulence factors within the Aeromonas species and supported the notion that different combinations, patterns, or 
genotypes of virulence determinants normally exist within the corresponding Aeromonas species. However, there is little consistency in the genes studied in all these reports; the most common were those encoding enterotoxins (ast, alt, act, aer), flagella (fla, laf), and lipases (gcat). There was even less consistency in the types of sampled assayed, the number of species tested, or the reference strains investigated. Clinical samples were the less explored in the studies using m-PCR and the gene combinations were not particularly useful for detecting the most prevalent virulence genes of strains isolated from different geographical areas $(2,7,10)$.

The above observations led us to develop a new in-house multiplex PCR, which we have termed pentaplex PCR (pPCR), as a rapid and effective method for the simultaneous detection of five genes encoding virulence factors that have shown the strongest relationship to diarrhoea in a single reaction $(2,20)$. The utility of this kind of PCR as a tool in this context is well-documented because it allows for the simultaneous detection of numerous genes $(13,14)$. It can be used not only as a tool for the continuous characterisation of the virulence potential of strains and their monitoring in environmental, human, and animal-origin samples, but also to identify which genes are present in the isolated strains and to describe the abundance and variation of these genes in these strains. In this study, the p-PCR was developed and compared with previous single-PCR (s-PCR) assays (2).

A total of 23 reference and type Aeromonas strains were analysed, and 54 clinical isolates from patients with diarrhoea were surveyed. All isolates were previously identified to the species level by the $16 S r R N A$ restriction fragment length polymorphism (RFLP) method $(2,6,16)$. The identified isolates (2) were grouped as follows: A. caviae $(\mathrm{n}=25)$, A. hydrophila ( $\mathrm{n}=18)$, and A. veronii $(\mathrm{n}=11)$. Pseudomonas aeruginosa ATCC 25668 and Vibrio parahaemolyticus CECT 611 and CECT 612 were used as controls for PCR amplifications. All strains were grown on tryptose soy agar (Oxoid, Cambridge, England) at $37^{\circ} \mathrm{C}$ for $18 \mathrm{~h}$.
PCR amplifications of gcat, ast, alt, aerolysin/haemolysin, and lafA virulence genes were performed as previously described (supplementary Table) by Aguilera-Arreola et al. (1) and Soler et al. (31). The generic term "aerolysin/haemolysin genes" is applied here because the primers reported by Soler et al. (31) amplify a number of genes encoding toxins known as aerolysin, aerolysin/haemolysin, haemolysin/aerolysin, haemolysin, and cytolytic enterotoxin. The primers lafA-F and lafA-R amplify similarly sized fragments of the consensus region of the genes lafA, lafA1, and lafA2 as they share $>80 \%$ similarity according to the CLUSTAL W analysis. Degenerated primers design was used to amplify these genes in different species. We used the basic local alignment search tool (BLAST) to show that the primers were unique and specific to their respective genes from different Aeromonas species, and did not match those of any other genus or species. PCR amplifications were performed in a final volume of $50 \mu \mathrm{l}$, containing $3 \mu \mathrm{g}$ of DNA template, $0.3 \mathrm{mM}$ deoxynucleotide triphosphate (dNTP) mix, 1X PCR buffer, $1.8 \mathrm{mM} \mathrm{MgCl}_{2}, 0.3$ $\mu \mathrm{M}$ primers, and 2.5 units of Taq polymerase (Gibco-BRL, Gaithersburg, MD). All reactions were carried out in a PerkinElmer DNA Thermal Cycler PCR System using programs previously described $(1,31)$. A simple (one gene) PCR was first performed for each of the reference and type strains of Aeromonas and subsequently for the non-Aeromonas reference strains. Gene fragments from the lateral flagella (lafA, 736-743 bp), aerolysin-hemolysis (aer/hem, 431 bp), heat labile enterotoxin (alt, 320 bp), heat-stable enterotoxin (ast, 504 bp), and glycerophospholipid acyltransferase (gcat, 237 bp) genes were amplified from genomic DNA. Two replicates were performed for each reaction. To verify the presence or absence of amplification products, $10 \mu \mathrm{l}$ from each PCR was electrophoresed on a $1 \%$ agarose gel. The remaining $40 \mu \mathrm{l}$ of the amplification reaction was kept frozen for other potential uses. Two random samples of the PCR amplification products for each of the target genes were authenticated by DNA sequencing with an ABI-PRISM ${ }^{\mathrm{TM}} 310$ (Applied Biosystems, 
Foster City, CA) following the standard methodology outlined by the manufacturer.

The standard multiplex PCR was performed in a buffer containing $20 \mathrm{mM}$ Tris-HCL (pH 8.4), $50 \mathrm{mM} \mathrm{KCl}, 1.8 \mathrm{mM}$ $\mathrm{MgCl} 2,300 \mu \mathrm{M}$ of each dNTP, $2.5 \mathrm{U}$ Taq polymerase, and 100 pg of genomic DNA in a $5-\mu 1$ volume. The primers for the lafA, aer/hem, and alt genes were used at a concentration of $0.15 \mu \mathrm{M}$, those for the ast gene were used at $0.10 \mu \mathrm{M}$, and those for the gcat gene were used at $25 \mu \mathrm{M}$. The cycling conditions were designed in two phases; in the first phase of 20 cycles, the gcat, aer/hem, and lafA genes were amplified; in the second phase of 15 cycles, the alt and ast genes were amplified. The cycling conditions in the first phase consisted of an initial single cycle at $95^{\circ} \mathrm{C}$ for $5 \mathrm{~min}$, followed by 20 cycles of melting at $94^{\circ} \mathrm{C}$ for $1 \mathrm{~min}$, annealing at $56^{\circ} \mathrm{C}$ for $1 \mathrm{~min}$, and elongation at $72^{\circ} \mathrm{C}$ for $1 \mathrm{~min}$. The second phase consisted of 15 cycles of melting at $94^{\circ} \mathrm{C}$ for $1 \mathrm{~min}$, annealing at $54^{\circ} \mathrm{C}$ for 1 min, and elongation at $72^{\circ} \mathrm{C}$ for $1 \mathrm{~min}$. A final and unique cycle at $72^{\circ} \mathrm{C}$ for $10 \mathrm{~min}$ was included. The p-PCR was first performed in each of the reference and type strains and subsequently in the non-Aeromonas reference strains. Then, the p-PCR was performed in the 54 clinical strains for specificity and sensitivity calculations (Table 1). To verify the presence or absence of amplification products, $10 \mu \mathrm{l}$ from each PCR was electrophoresed on a $1 \%$ agarose gel. The products of simultaneous p-PCR reactions of each gene were confirmed via DNA sequencing on an ABI-PRISM 310 (Applied Biosystems, Foster City, CA) following the standard methodology outlined by the manufacturer. As in the single PCR assay, each reaction was performed in duplicate.

Table 1. Combinations of enterotoxins and adherence related genes harboured in 54 clinical Aeromonas isolates.

\begin{tabular}{|c|c|c|c|c|}
\hline \multirow[t]{2}{*}{ Possible combinations } & \multicolumn{3}{|c|}{ Number positive strains for analysed combination } & \multirow{2}{*}{$\begin{array}{l}\text { Total positive strains } \\
\text { for } \mathrm{p}-\mathrm{PCR} / \mathrm{s}-\mathrm{PCR}\end{array}$} \\
\hline & A. hydrophila $(\mathrm{n}=18)$ & A. caviae $(\mathrm{n}=25)$ & A. veronii $(\mathrm{n}=11)$ & \\
\hline None & $0 / 0$ & $3 / 3$ & $0 / 0$ & $3 / 3$ \\
\hline aer/hem & $0 / 0$ & $13 / 13$ & $7 / 7$ & $20 / 20$ \\
\hline aer/hem + alt & $0 / 0$ & $1 / 1$ & $3 / 3$ & $4 / 4$ \\
\hline aer/hem + ast & $0 / 0$ & $1 / 1$ & $0 / 0$ & $1 / 1$ \\
\hline aer/hem + lafA & $0 / 0$ & $5 / 5$ & $1 / 1$ & $6 / 6$ \\
\hline alt + ast & $1 / 0$ & $0 / 0$ & $0 / 0$ & $1 / 0$ \\
\hline alt + lafA & $0 / 0$ & $1 / 1$ & $0 / 0$ & $1 / 1$ \\
\hline aer/hem + alt + lafA & $0 / 0$ & $1 / 1$ & $0 / 0$ & $1 / 1$ \\
\hline alt $+a s t+l a f \mathrm{~A}$ & $6 / 6$ & $0 / 0$ & $0 / 0$ & $6 / 6$ \\
\hline aer/hem + alt + ast & $0 / 1$ & $0 / 0$ & $0 / 0$ & $0 / 1$ \\
\hline aer/hem + alt + ast + lafA & $11 / 11$ & $0 / 0$ & $0 / 0$ & $11 / 11$ \\
\hline Total & 18 & 25 & 11 & $54 / 54$ \\
\hline$\%$ Sensitivity & 100 & 100 & 100 & $100 \%$ \\
\hline$\%$ Specificity & 50 & 100 & 100 & $83.3 \%$ \\
\hline
\end{tabular}

Genes encoding: aerolysin/hemolysin (aer/hem), thermo labile cytotonic enterotoxin (alt), thermo stable cytotonic enterotoxin (ast), and lateral flagella (lafA). *result obtained from two replicates.

The sensitivity of the p-PCR assay was evaluated by comparing the results of the multiplex PCR with those obtained by single PCRs. The sensitivity and specificity, as well as the positive and negative predictive values, were calculated by $2 \times$ 2 contingency tables in a Microsoft Excel ${ }^{\circledR}$ spreadsheet.

All 23 reference and type strains used for the simple PCR produced at least some of the expected amplicons. These strains harbour several combinations of virulence factor genes. The strains with the greatest number of virulence genes were $A$. hydrophila, A. bestiarum, A. salmonicida subsp. mausocida, and $A$. salmonicida subsp. achromogenes, whereas the strains with the fewest were $A$. media, $A$. schubertii, and the $A$. HG11 group.

In general, there was a wide variety in the combinations of 
virulence factors in the Aeromonas clinical isolates. The general abundance of the genes has been previously demonstrated (2). Table 1 shows the different combinations of enterotoxin and adherence-related genes detected by s-PCR in the previously mentioned study and the replicates did likewise in the present study.

The accuracy of the p-PCR assay was evaluated by comparison with the results from the s-PCR, revealing a specificity of $96 \%$ and a sensitivity of $91.84 \%$. Therefore, use of the primer combination for the clinical isolates was justified by the reliability of the p-PCR design method (Figure 1). The primer combination's specificity for Aeromonas was demonstrated by the negative PCR results obtained with all of the non-Aeromonas reference strains. The sensitivity and specificity were higher in the reference and type strains and in the clinical ones (Table 1). Two replicates for each reaction (strain) was performed and results were consistent in both. The major incongruities between p-PCR and s-PCR were found in the genes aer/hem since in five reference strains there was no correlation, in contrast to the clinical strains where only one inconsistency between both methods was detected. In the lafA genes, a single inconsistence was observed in A. salmonicida subsp. achromogenes reference strain; whereas no inconsistencies were detected in the other three genes tested.

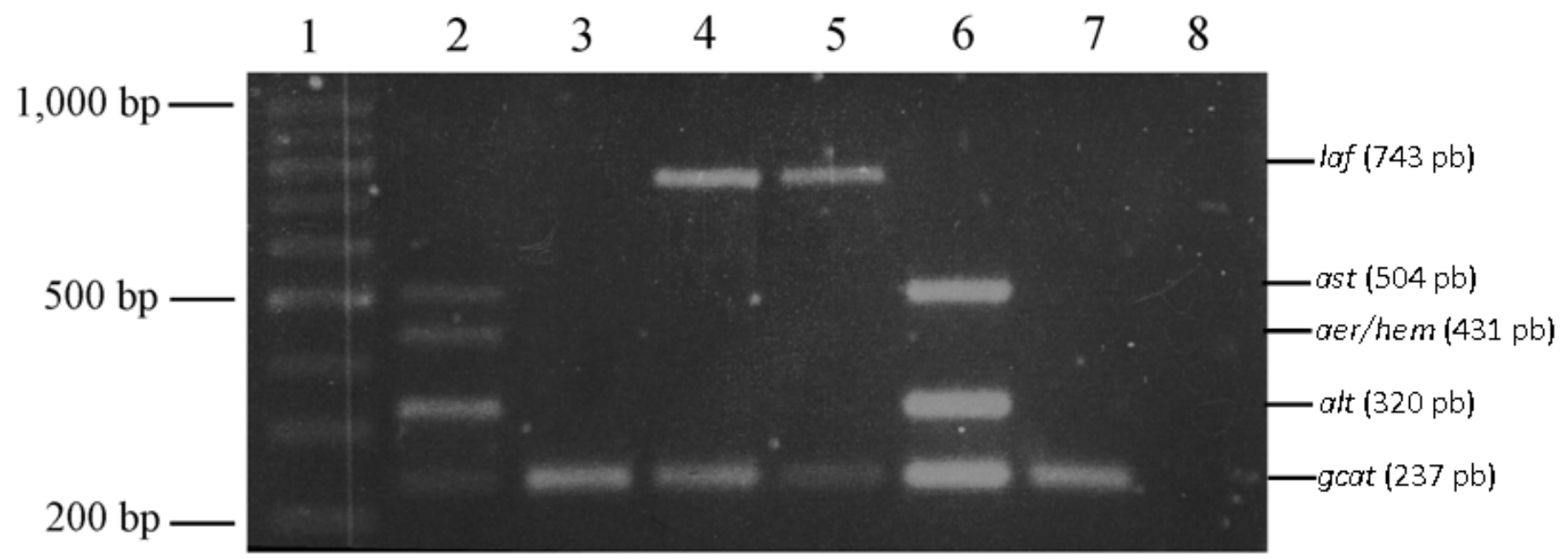

Figure 1. Pentaplex-PCR amplifications in Aeromonas type and clinical isolates. Lanes: 1, 100 pb DNA Molecular size marker $\left(\right.$ Amresco $\left.^{\circledR}\right) ; 2$, A. hydrophila CECT 839; 3 and 7, A. caviae 44H; 4 and 5, A. caviae CECT 838; 6. A. hydrophila 180H; 8, negative control.

Because it has been impossible, so far, to establish a hierarchical classification of virulence factors according to their role in Aeromonas pathogenesis, several studies, via PCR or hybridisation assays, have been performed to find one single virulence factor (s-PCR) or defined combinations of virulence factors (m-PCR) in the different Aeromonas species. The early work performed by Sen and Rodgers (28) reported the distribution of six virulence factors in Aeromonas from drinking water utilities, achieving this result through three sets of duplex PCR (d-PCR) addressed to search for two enterotoxin genes (act and alt), one gene of constitutive adherence (fla), and two genes considered accessory virulence genes (lipase and elastase genes), whereas the p-PCR, described herein, detects also five genes, it does so in a single 
reaction and the detected genes are the ones related with diarrhoea, alt, ast, and aer/hem enterotoxin genes; laf genes related with adherence and biofilm mechanisms and gcat, an unusual lipase gene, which participates in pathogenicity and is useful as a tool for genus identification (9). Other authors have proposed a simpler design, standardising a d-PCR to detect specifically pathogenic A. hydrophila strains in fish; their dPCR is capable of amplifying the $16 S$ rRNA gene and the aerolysin gene. This method has been useful for the direct detection of pathogenic strains of $A$. hydrophila (12) while the current p-PCR proposed herein is addressed to most species of the Aeromonas genus.

The most complex m-PCR was probably that described by Nam and Joh (26). These authors reported the rapid detection of virulence factors of Aeromonas isolated from a trout farm by a hexaplex PCR (h-PCR) designed to detect virulence accessory genes (nuclease, serine protease, and lipase) and aerolysin, gcat, and lateral flagella genes, the set of genes proposed by these authors is better suited to detect important virulence factors in sick fish $(8,10)$. However, ast, alt, act, and aer/hem enterotoxin genes that show the strongest relationship with diseases in humans were not included. These authors concluded that their h-PCR could be used to rapidly screen and detect virulence factors from major Aeromonas species isolated from trout farms; whereas the p-PCR described by us could represent a more concrete method for both clinical and animalorigin isolates.

In contrast, Chang et al. (11) designed a triplex PCR (tPCR) to amplify only the cytotoxic (act), heat-labile (alt), and heat-stable cytotonic (ast) enterotoxin genes of aeromonads in 133 strains isolated from food and retail samples of poultry and fish. This method (t-PCR) has been useful for the detection and genotyping of enterotoxin genes of aeromonads. The analysed isolates were divided into six genotypes or patterns. A. caviae and $A$. hydrophila were the most frequently isolated species, and a significantly higher proportion of the former strains harboured all three of these enterotoxin genes. Recently, a second t-PCR method for the detection of the same three enterotoxin genes (act, alt, and ast) was described by Kingombe et al. (22). Although the last two studies had similar designs, the latter characterised a wider range of reference strains, as well as foodborne isolates, finding seven gene pattern combinations; the act and alt genes were the most dominant in the analysed isolates. In this context, the proposed p-PCR includes all these enterotoxins and, in addition, allows for the amplification of two more suitable characteristics of virulence, important not only for food samples but also for clinical samples.

In previous studies, we demonstrated that the lafA, ast, alt, and aer/hem genes are the most frequent ones of clinical relevance in Aeromonas in Mexico and Spain (2). There, the use of independent PCR amplifications was a good approach. However, because of the large number of strains to be analysed in that study, a dot-blot hybridization assay was performed, and few discrepancies between the PCR and dot-blot detection were found. Due to the advantages that have been reported in the use of m-PCR, we decided to test the same eight primers used in our previous study to amplify these four target genes together in an m-PCR. The gcat gene was integrated into the pPCR because it is marker gene for the Aeromonas genus as well as a significant virulence gene (8). The results were satisfactory; the pentaplex reaction showed good specificity and sensitivity in both type strains and clinical isolates. Thus, the p-PCR system developed in this study reduces the analyses time. It promises to be a powerful tool for more accurate risk assessments and for the monitoring of pathogenic strains of the most frequently isolated Aeromonas species, A. hydrophila, A. caviae, and $A$. veronii and other species. Of course, the reduced performance could be a problem of the number of samples analysed or the intraspecific variability previously shown in the Aeromonas genus $(1,24)$; however, both hypotheses should be confirmed with a larger set of strains than tested currently.

We developed and evaluated a pentaplex PCR assay for the rapid detection of putative virulence factors in Aeromonas. 
Although sophisticated surveys of pathogenicity mechanisms have already been conducted, the detection of enterotoxin genes by PCR remains a good approach to estimate virulence potential in Aeromonas. The p-PCR technique will be valuable as a simple tool to screen for the presence of virulent strains because the specific combination of genes employed facilitates the identification of the Aeromonas genus and characterize sick fish, particularly fish intended for human consumption, as well as waterborne bacteria and extra-intestinal clinical strains that are commonly analysed at clinical, research, or reference laboratories.

\section{ACKNOWLEDGEMENTS}

M.G.A.A. and G.C.E. received COFAA, EDI and SNI support. This work was financially supported by grants 20090729 and 20100252 from SIP-IPN, Mexico City. We would like to thank to Dr. Maria Jose Figueras from the Universitat Rovira i Virgili and Dra. Miroslava Sánchez from the Laboratorio de Salud Pública for kindly providing isolates.

\section{REFERENCES}

1. Aguilera-Arreola, M.G.; Hernández-Rodríguez, C.; Zuñiga, G.; Figueras, M.J.; Castro-Escarpulli, G. (2005). Aeromonas hydrophila clinical and environmental ecotypes as revealed by genetic diversity and virulence genes. FEMS Microbiol. Lett., 242, 231-240. doi:10.1016/j.femsle.2004.11.011

2. Aguilera-Arreola, M.G.; Hernández-Rodríguez, C.H.; Zúñiga, G.; Figueras, M.J.; Garduño, R.A.; Castro-Escarpulli, G. (2007). Virulence potential and genetic diversity of Aeromonas caviae, Aeromonas veronii, and Aeromonas hydrophila clinical isolates from Mexico and Spain: a comparative study. Can. J. Microbiol., 53 (7), 877-887. doi:10.1139/W07-051

3. Alperi, A.; Martínez-Murcia, A.J.; Ko, W.C.; Monera, A.; Saavedra, M.J.; Figueras, M.J. (2009). Aeromonas taiwanensis sp. nov. and Aeromonas sanarellii sp. nov., two new clinical species from Taiwan. Int. J. Syst. Evol. Microbiol., $60 \quad$ (9), 2048-2055. doi:10.1099/ijs.0.014621-0.

4. Alperi, A.; Martínez-Murcia, A.J.; Monera, A.; Saavedra, M.J.; Figueras, M.J. (2010). Aeromonas fluvialis sp. nov., isolated from a Spanish river.
Int. J. Syst. Evol. Microbiol., 60 (1), 72-77. doi:10.1099/ijs.0.011643-0.

5. Beaz-Hidalgo, R.; Alperi, A.; Figueras, M.J.; Romalde, J.L. (2009). Aeromonas piscicola sp. nov., isolated from diseased fish. Syst. Appl. Microbiol., 32 (7), 471-479. doi:10.1016/j.syapm.2009.06.004.

6. Borrell, N.; Acinas, S.G.; Figueras, M.J.; Martínez-Murcia, A.J. (1997). Identification of Aeromonas clinical isolates by restriction fragment length polymorphism of PCR-amplified $16 S$ rRNA genes. J. Clin. Microbiol., 35(7): 1671-1674.

7. Castilho, M.C.; Castro, T.L.; Araújo, V.S.; Trajano, R.S.; Santos, P.A.; Pimenta, P.M.; Lucheze, K.; Melo, J.T.; Gonçalves, A.M.; Nogueira, R.T.; de Luna, M.G.; Freitas-Almeida, A.C. (2009). High frequency of hemolytic and cytotoxic activity in Aeromonas spp. isolated from clinical, food and environmental samples in Rio de Janeiro, Brazil. Antonie Van Leeuwenhoek., 96 (1), 53-61. doi:10.1007/s10482-0099335-6.

8. Castro-Escarpulli, G.; Figueras, M.J.; Aguilera-Arreola, M.G.; Soler, L.; Fernández-Rendón, E.; Aparicio, G.O.; Guarro, J.; Chacón, M.R. (2003). Characterisation of Aeromonas spp. isolated from frozen fish intended for human consumption in Mexico. Int. J. Food Microbiol., 84 (1), 41-49.

9. Chacón, M.R.; Castro-Escarpulli, G.; Soler, L.; Guarro, J.; Figueras, M.J. (2002). A DNA probe specific for Aeromonas colonies. Diagn. Microbiol. Infect. Dis., 44 (3), 221-225. doi:10.1016/S07328893(02)00455-8.

10. Chacón, M.R.; Figueras, M.J.; Castro-Escarpulli, G.; Soler, L.; Guarro, J. (2003) Distribution of virulence genes in clinical and environmental isolates of Aeromonas spp. Antonie Van Leeuwenhoek., 84 (4), 269-278.

11. Chang, Y.C.; Wang, J.Y.; Selvam, A.; Kao, S.C.; Yan, S.S.; Shih, D.Y. (2008). Multiplex PCR detection of enterotoxin genes in Aeromonas spp. from suspect food samples in northern Taiwan. J. Food Prot., 71 (10), 2094-2099.

12. Chu, W.H.; Lu, C.P. (2005). Multiplex PCR assay for the detection of pathogenic Aeromonas hydrophila. J. Fish. Dis., 28 (7), 437-441. doi:10.1111/j.1365-2761.2005.00628.x

13. Edwards, M.C.; Gibbs, R.A. 1994. Multiplex PCR: advantages. Genome Res., 3, S65-S75.

14. Elnifro, E.M.; Ashshi, A.M.; Cooper, R.J.; Klapper, P.E. (2000). Multiplex PCR: optimization and application in diagnostic virology. Clin. Microbiol. Rev., 13, 559-570.

15. Fadl, A.A.; Galindo, C.L.; Sha, J.; Zhang, F.; Garner, H.R.; Wang, H.Q.; Chopra, A.K. (2007). Global transcriptional responses of wild-type Aeromonas hydrophila and its virulence-deficient mutant in a murine model of infection. Microb. Pathog., 42 (5-6), 193-203. doi:10.1016/j.micpath.2007.02.002

16. Figueras, M.J.; Soler, L.; Chacón, M.R.; Guarro, J.; Martínez-Murcia, A.J. (2000). Extended method for discrimination of Aeromonas spp. by 16S rDNA RFLP analysis. Int. J. Syst. Evol. Microbiol., 50 (6), 2069- 
2073.

17. Figueras, M.J.; Alperi, A.; Beaz-Hidalgo, R.; Stackebrandt, E.; Brambilla, E.; Monera, A.; Martínez-Murcia, A.J. (2010). Aeromonas rivuli sp. nov. isolated from the upstream region of a karst water rivulet in Germany. Int. J. Syst. Evol. Microbiol., 61 (2), 242-248. doi:10.1099/ijs.0.016139-0

18. Gavín, R.; Rabaan, A.A.; Merino, S.; Tomás, J.M.; Gryllos, I.; Shaw, J.G. (2002). Lateral flagella of Aeromonas species are essential for epithelial cell adherence and biofilm formation. Mol Microbiol., 43 (2), 383-397.

19. Guerra, I.M.F.; Fadanelli, R.; Figueiró M.; Shreiner, F.; Delamare A.P.L.; Wollheim C.; Costa S.O.P.; Echeverrigaray S. (2007). Aeromonas associated diarrhoeal disease in south brazil: prevalence, virulence factors and antimicrobial resistance. Braz. J. Micriobiol., 38, 638-643. doi: 10.1590/S1517-83822007000400011

20. Janda, J.M.; Abbott, S.L. (2010). The genus Aeromonas: taxonomy, pathogenicity, and infection. Clin. Microbiol. Rev., 23 (1), 35-73. doi:10.1128/CMR.00039-09

21. Kingombe, C.I.; Huys, G.; Tonolla, M.; Albert, M.J.; Swings, J.; Peduzzi, R.; Jemmi, T. (1999). PCR detection, characterization, and distribution of virulence genes in Aeromonas spp. Appl. Environ. Microbiol., 65 (12), 5293-5302.

22. Kingombe, C.I.; D'Aoust, J.Y.; Huys, G.; Hofmann, L.; Rao, M.; Kwan, J. (2010). Multiplex PCR method for detection of three Aeromonas enterotoxin genes. Appl. Environ. Microbiol., 76 (2), 425-433. doi:10.1128/AEM.01357-09

23. Martin-Carnahan, A.; Joseph, S.W. (2005). Aeromonas. In Bergey's Manual of Systematic Bacteriology, 2nd edn, vol. 2, pp. 556-578. Edited by D. J. Brenner, N. R. Krieg, J. T. Staley \& G. M. Garrity. New York: Springer.

24. Miñana-Galbis, D.; Farfán, M.; Fusté, M.C.; Lorén, J.G. (2004). Genetic diversity and population structure of Aeromonas hydrophila, Aeromonas bestiarum, Aeromonas salmonicida and Aeromonas popoffii by multilocus enzyme electrophoresis (MLEE). Environ. Microbiol., 6 (3), 198-208. doi: 10.1046/j.1462-2920.2004.00554.x

25. Miñana-Galbis, D.; Farfán, M.; Lorén, J. G.; Fusté, M.C. (2010). Proposal to assign Aeromonas diversa sp. nov. as a novel species designation for Aeromonas group 501. Syst. Appl. Microbiol., 33 (1), $15-$ 19. doi:10.1016/j.syapm.2009.11.002

26. Nam, I.Y.; Joh, K. 2007. Rapid detection of virulence factors of Aeromonas isolated from a trout farm by hexaplex-PCR. J. Microbiol., 45 (4), 297-304

27. Sechi, L.A.; Deriu, A.; Falchi, M.P.; Fadda, G.; Zanetti, S. (2002). Distribution of virulence genes in Aeromonas spp. isolated from Sardinian waters and from patients with diarrhoea. J. Appl. Microbiol., 92 (2), 221-227. doi:10.1046/j.1365-2672.2002.01522.x

28. Sen, K.; Rodgers, M. (2004). Distribution of six virulence factors in Aeromonas species isolated from US drinking water utilities: a PCR identification. J. Appl. Microbiol., 97 (5), 1077-1086. doi:10.1111/j.1365-2672.2004.02398.x

29. Sen, K.; Lye, D. (2007). Importance of flagella and enterotoxins for Aeromonas virulence in a mouse model. Can. J. Microbiol., 53 (2), 261269. doi:10.1139/W06-095

30. Sha, J.; Kozlova, E.V.; Chopra, A.K. (2002). Role of various enterotoxins in Aeromonas hydrophila-induced gastroenteritis: generation of enterotoxin gene-deficient mutants and evaluation of their enterotoxic activity. Infect. Immun., 70 (4), 1924-1935. doi: 10.1128/IAI.70.4.1924-1935.2002.

31. Soler, L.; Figueras, M.J.; Chacón, M.R.; Vila, J.; Marco, F.; MartínezMurcia, A.J.; Guarro, J. (2002). Potential virulence and antimicrobial susceptibility of Aeromonas popoffii recovered from freshwater and seawater. FEMS Immunol. Med. Microbiol., 32 (3), 243-247. doi: 10.1111/j.1574-695X.2002.tb00560.x 